\title{
Gallium(III) chelates of mixed phosphonate-carboxylate triazamacrocyclic ligands relevant to nuclear medicine: structural, stability and in vivo studies
}

Maria I. M. Prata, ${ }^{1}$ João P. André, ${ }^{2}$ Zoltán Kovács,${ }^{3}$ Anett I. Takács, ${ }^{4}$ Gyula Tircsó,${ }^{4}$ Imre Tóth, ${ }^{4}$ Carlos F.G.C. Geraldes ${ }^{5 *}$

${ }^{1}$ ICNAS, Universidade de Coimbra, Azinhaga de Santa Comba, 3000-548 Coimbra, Portugal

${ }^{2}$ Centro de Química, Campus de Gualtar, Universidade do Minho, 4710-057 Braga, Portugal

${ }^{3}$ Advanced Imaging Research Center, University of Texas Southwestern Medical Center at Dallas, 5323 Harry Hines Blvd, Dallas, TX 75390, USA

${ }^{4}$ Department of Inorganic and Analytical Chemistry, Faculty of Science and Technology, University of Debrecen, Egyetem tér 1, H-4010, Debrecen, Hungary

${ }^{5}$ Department of Life Sciences and Coimbra Chemistry Center, University of Coimbra, Coimbra, Portugal

\section{CORRESPONDING AUTHOR:}

*Carlos F. G. C Geraldes, Department of Life Sciences, Faculty of Science and Technology, University of Coimbra, Calçada Martim de Freitas, 3000-393 Coimbra, Portugal. Tel.: +351239240730, e-mail: geraldes@ci.uc.pt 


\begin{abstract}
Three triaza macrocyclic ligands, NOTP, NO2AP and NOA2P, and their gallium(III) chelates were studied in view of their potential interest as scintigraphic and PET imaging agents. $\mathrm{A}{ }^{1} \mathrm{H},{ }^{31} \mathrm{P}$ and ${ }^{71} \mathrm{Ga}$ multinuclear NMR study gave an insight on the structure, internal dynamics and stability of the chelates in aqueous solution. In particular, the analysis of ${ }^{71} \mathrm{Ga}$ NMR spectra gave information on the symmetry of the $\mathrm{Ga}^{3+}$ coordination sphere and the stability of the chelates towards hydrolysis. The ${ }^{31} \mathrm{P}$ NMR spectra afforded information on the protonation of the non-coordinated oxygen atoms from the pendant phosphonate groups and on the number of species in solution. The ${ }^{1} \mathrm{H}$ NMR spectra allowed the analysis of the structure and the number of species in solution.

${ }^{31} \mathrm{P}$ and ${ }^{1} \mathrm{H}$ NMR titrations combined with potentiometry afforded the measurement of the protonation constants $\left(\log K_{\mathrm{Hi}}\right)$ and the microscopic protonation scheme of the triaza macrocyclic ligands. The remarkably high thermodynamic stability constant $\left(\log K_{\mathrm{GaL}}=\right.$ $34.44(0.04)$ and stepwise protonation constants of $\mathrm{Ga}(\mathrm{NOA} 2 \mathrm{P})^{2-}$ were determined by potentiometry and ${ }^{69} \mathrm{Ga}$ and ${ }^{31} \mathrm{P}$ NMR titrations. Biodistribution and gamma imaging studies have been performed on Wistar rats using the radiolabeled ${ }^{67} \mathrm{Ga}(\mathrm{NO} 2 \mathrm{AP}){ }^{-}$and ${ }^{67} \mathrm{Ga}(\mathrm{NOA} 2 \mathrm{P}){ }^{2-}$ chelates, having both demonstrated to have renal excretion. The correlation of the molecular properties of the chelates with their pharmacokinetic properties has been analysed.
\end{abstract}

Keywords: NMR; triaza; phosphinates; gamma imaging, PET, gallium 


\section{Introduction}

The importance of gallium chelates in nuclear medicine has led to an increasing interest in the coordination chemistry of this metal ion. The use of $\mathrm{Ga}^{3+}$ in clinical applications such as nuclear scintigraphy $\left({ }^{67} \mathrm{Ga} ; \gamma, \mathrm{t}_{1 / 2} 3.35\right.$ days $)$ and particularly in positron emission tomography, PET, $\left({ }^{68} \mathrm{Ga} ; \beta^{+}, \mathrm{t}_{1 / 2} 68 \mathrm{~min}\right)$ is in rapid expansion [1-6]. Most of the ${ }^{67 / 68} \mathrm{Ga}$ radiopharmaceuticals belong to the class of gallium bioconjugates where a $\mathrm{Ga}^{3+}$ chelate is covalently linked to a biomolecule that is able to recognize a biological function, e.g. a receptor. High thermodynamic and kinetic stabilities are required for in vivo applications of the metal chelates, ensuring that the radiopharmaceutical remains intact during its lifetime in the body [7-9]. Triaza macrocyclic ligands are particularly appropriate to complex ${ }^{67 / 68} \mathrm{Ga}^{3+}$ due to their high conformational and size selectivities towards this metal ion allowing a proper fit of the relatively small cation in the triaza cavity [10].

The kinetics of complexation and dissociation processes, as well as the solution structures of the chelates are affected by the number and nature of the substituent groups bound to the nitrogen atoms of the macrocyclic ring. Ligands with different types of pendant arms (carboxylates [11-15], phosphinates [16-19] and phosphonates [20]) have shown to be very suitable ligands for $\mathrm{Ga}^{3+}$.

The $\mathrm{Ga}^{3+}$ triaza chelates present symmetric crystal structures with the metal ion in a more or less distorted octahedral coordination polyhedron, showing a $C_{3}$ symmetry axis. The three nitrogen atoms occupy one facial plane and the oxygen atoms from the pendant arms occupy the other almost parallel face $\left(\mathrm{N}_{3} \mathrm{O}_{3}\right.$ systems). The degree of distortion of their crystal structures from regular octahedral coordination is defined by the relative twist angle $(\theta)$ of the $\mathrm{N}_{3}$ and $\mathrm{O}_{3}$ planes from the symmetrical staggered conformation. ${ }^{69} \mathrm{Ga}$ and ${ }^{71} \mathrm{Ga}$ 
are quadrupolar nuclei and therefore the linewidths of the NMR signals they originate are determined by the electric field gradients present in the distorted $\mathrm{Ga}^{3+}$ coordination polyhedron. Thus the ${ }^{69} \mathrm{Ga}$ and ${ }^{71} \mathrm{GaNMR}$ signal linewidths can be used as a sensitive measure of that degree of distortion in solution [21].

In the continuation to our studies on the aqueous solution chemistry and structure of metal chelates of triaza-based ligands of potential interest for diagnostic purposes $[14,15,20,22-$ 25] we have performed a potentiometric and multinuclear $\left({ }^{1} \mathrm{H},{ }^{31} \mathrm{P},{ }^{13} \mathrm{C}\right.$ and $\left.{ }^{69 / 71} \mathrm{Ga}\right) \mathrm{NMR}$ study of three triaza macrocyclic ligands differing in the number of carboxylate and phosphonate pendant arms (conferring varying overall charge to the chelates): $\mathrm{H}_{6} \mathrm{NOTP}$ (1,4,7-triazacyclononane- $N, N^{\prime}, N^{\prime \prime}$-trimethylene phosphonic acid), $\mathrm{H}_{4} \mathrm{NO} 2 \mathrm{AP}$ (1,4,7triazacyclononane- $N$-methylenephosphonic acid- $N^{\prime}, N^{\prime \prime}$-dimethylenecarboxylic acid), and $\mathrm{H}_{5}$ NOA2P (1,4,7-triazacyclononane- $N, N^{\prime}$-bis(methylenephosphonic acid)- $N^{\prime \prime}$ - methylene carboxylic acid) (Fig.1) and of their $\mathrm{Ga}^{3+}$ chelates in aqueous solution. These studies include the determination of the stepwise protonation constants and microscopic protonation scheme of the ligands, as well as the thermodynamic stability constant and protonation constants of $\mathrm{Ga}(\mathrm{NOA} 2 \mathrm{P})^{2-}$. The conformation, dynamics and symmetry of the $\mathrm{Ga}^{3+}$ coordination sphere of the GaL chelates were studied by multinuclear NMR. Finally, to elucidate the influence of the charge and type of pendant arms (carboxylate versus phosphonate) on their in vivo properties, the behaviour of the ${ }^{67} \mathrm{Ga}$ chelates of $\mathrm{NO}_{2} \mathrm{AP}^{4-}$ and NOA2 $\mathrm{P}^{5-}$ was investigated by gamma-imaging and biodistribution studies in Wistar rats and was compared with our previous results on ${ }^{67} \mathrm{Ga}(\mathrm{NOTP}){ }^{3-}[22]$.

\section{Results and Discussion}

\subsection{Determination of protonation and stability constants}


The equilibrium reactions in the $\mathrm{Ga}^{3+}-\mathrm{L}-\mathrm{H}^{+}$(where $\mathrm{L}$ denotes the multidentate ligand) ternary systems can be described by the following equations, where all the overall equilibrium constants $(\beta)$ are concentration quotients rather than activities and are defined as:

$$
\begin{aligned}
& \mathrm{Ga}^{3+}+\mathrm{i} \mathrm{H}^{+}+\mathrm{L}^{\mathrm{i}-} \rightleftharpoons \quad \mathrm{H}_{\mathrm{iGaL}} \\
& \beta=\frac{\left[\mathrm{H}_{\mathrm{i}} \mathrm{GaL}\right]}{\left[\mathrm{Ga}^{3+}\right]\left[\mathrm{H}^{+}\right]^{\mathrm{i}}\left[\mathrm{L}^{\mathrm{i}-}\right]}
\end{aligned}
$$

In the absence of $\mathrm{Ga}^{3+}(1)$ and (2) refer to the protonation equilibria of the ligands, and the respective constants are represented as $\log K_{\mathrm{Hi}}$.

The protonation constants, $\log K_{\mathrm{Hi}}$, of the ligands NOTP and NOA2P as defined in equation (1) and (2), were determined by $\mathrm{pH}$-potentiometric titrations at $\mathrm{I}=0.1 \mathrm{M} \mathrm{KCl}$ and $25^{\circ} \mathrm{C}$, except for $\log K_{H 1}$, which was determined by ${ }^{31} \mathrm{P}$ NMR titration (see below), as its existence was proved by titrating the ligand in the presence of a large $\mathrm{Ca}^{2+}$ excess. The potentiometric titrations were performed in the $\mathrm{pH}$ range of $1.80-11.80$ for the ligand (ESI Fig. S1) and 12.35-2.04 (see Fig. 2 as an example) since the formation of the $\mathrm{Ga}^{3+}$ complexes is fast under these conditions.

Table 1 presents the calculated protonation constants based on potentiometry and ${ }^{31} \mathrm{P} N M R$ spectroscopy data, and compares them with values reported previously for NOTP [26] and NOTA [27-30]. The lowest constants $\left(\log K_{\mathrm{Hn}}<2\right)$ are close to the limit of potentiometry and they have higher uncertanties. The values of first constants $\left(\log K_{\mathrm{H} 1}\right)$ for NOTP and NOA2P have been measured by ${ }^{31} \mathrm{P}$ NMR (Fig. S2). It is worth noting that the ${ }^{31} \mathrm{P}$ NMR chemical shift - pH curve of NOA2P (Fig. 3) shows a bell-shaped character in the pH $=1.8-10$ range and cannot be fitted by the 4 protonation constants measured by 
potentiometry. However, the chemical shift - $\mathrm{pH}$ data points (where $\mathrm{pH}=14+\log \mathrm{C}_{\mathrm{KOH}}$, $\left.\mathrm{C}_{\mathrm{KOH}}=0.1-10\right)$ can be fitted by a value of $\log K_{\mathrm{H} 1}=14.21 \pm 0.09$ (Fig. 3). This value is much higher than those obtained previously for NOTP by potentiometry in $0.1 \mathrm{M} \mathrm{NaCl}$ (11.7) or $0.1 \mathrm{M} \mathrm{NMe}_{4} \mathrm{Cl}$ (12.1) [26], indicating the competing effect of complex formation of the respective cations by the ligand on its protonation. In a previous study, it was observed that the ${ }^{1} \mathrm{H}$ and ${ }^{31} \mathrm{P}$ NMR $\mathrm{pH}$ titration curves obtained for NOTP in $0.1 \mathrm{M} \mathrm{NMe} \mathrm{Cl}_{4}$ had an inflexion at high $\mathrm{pH}$, indicating a first ligand protonation at $\mathrm{pH}$ well above 12 [26]. It is well known that the substitution of methylenephosphonate groups on the nitrogen atom of the parent cyclic amine results in a large increase in the first protonation constant of the macrocyclic phosphonate ligands, with values well above 14.0, which can only be obtained by NMR pH titrations, as observed here for NOTP and NOA2P (with $\log \mathrm{K}_{\mathrm{H} 1}$ around 14.21, see Table 1) and by others for the tetraaza macrocyclic analogue DOTP $\left(\log \mathrm{K}_{\mathrm{H} 1}=\right.$ 14.65) [31]. The effect of substituent methylenephosphonate groups on the protonation of a nitrogen site is much stronger than that of methylenecarboxylate groups, as seen by the much lower $\log \mathrm{K}_{\mathrm{H} 1}$ value of NOTA (Table 1). The second protonation step, like the first one, also involves protonation of the macrocyclic ring nitrogens $[26,27]$. The $\log \mathrm{K}_{\mathrm{H} 2}$ value is much higher for the phosphonate ligands NOTP and NOA2P than for the carboxylate ligand NOTA. This shows that the difference between the effects of the methylenephosphonate and acetate functionalities on the basicity of the nitrogen atoms in the monoprotonated form of the ligand is basically maintained, although the electrostatic and inductive effects of those substituent groups may be somewhat altered by the formation of intramolecular hydrogen bonds. Further protonation detected for NOTP and NOA2P occurs at the phosphonate and carboxylate pendant groups (Table 1). The sequence of 
microscopic protonation sites of NOTP, NOA2P and NO2AP was further studied in detail by ${ }^{1} \mathrm{H}$ NMR $\mathrm{pH}$ titrations and is discussed in the SI.

The equilibrium reactions in the $\mathrm{Ga}^{3+}-\mathrm{L}-\mathrm{H}^{+}$ternary system can also be described by equations (1) and (2), where $\mathrm{i}=1,2,3$ mean protonated complexes, while $\mathrm{i}=-1$ or -2 means mixed hydroxo complexes. A detailed equilibrium study has been done for the NOA2P ligand. The triaza macrocyclic ligands are known to form very stable complexes with the $\mathrm{Ga}^{3+}$ ion. The formation of the $\mathrm{GaL}$ or $\mathrm{H}_{\mathrm{x}} \mathrm{GaL}$ species is often complete in very acidic solution $(\mathrm{pH} \leq 2)$, therefore $\mathrm{pH}$-potentiometry based on $\mathrm{H}^{+}$- metal ion competition is not suitable to measure the thermodynamic stability constant. An additional serious technical problem is related to the slow formation of complexes in acidic solutions, [32] which requires a long time for equilibration, i.e. direct potentiometry cannot be used, and preparation of separated samples and long waiting times are needed to measure stability constants. In some cases there is a definite need for combination with competition using secondary ligands and/or metal ions. Fortunately, gallium is an amphotheric element and the $\mathrm{Ga}^{3+}$ ion forms very stable complexes with $\mathrm{OH}^{-}$, i.e. one can use the hydroxide as a competitor ligand in the alkaline region. An additional advantage of the high $\mathrm{pH}$ is that the complex formation is likely quite fast at $\mathrm{pH} \geq 8$, therefore we could use direct potentiometry titration in the $\mathrm{Ga}^{3+}-\mathrm{NOA}_{2} \mathrm{P}^{5-}-\mathrm{H}^{+}$system from $\mathrm{pH}=12.6$ to $\mathrm{pH}=8$ to evaluate the stability constant(s) with relatively short waiting time for equilibrium. Following the titration of the already equilibrated system from $\mathrm{pH}=8$ to 1.8 one can get the protonation constants of the $\mathrm{H}_{\mathrm{x}} \mathrm{GaL}$ species without any dissociation of the complexes. The stability constants are summarized in Table 2 together with data for several $\mathrm{Ga}^{3+}$ complexes for comparison. 
The thermodynamic stability constant of $\mathrm{Ga}(\mathrm{NOA} 2 \mathrm{P})^{2-}\left(\log \beta_{\mathrm{GaL}}=34.44\right)$ is much higher than the previously reported values for Ga(NOTA) [19] and $\mathrm{Ga}(\mathrm{DOTA})$ [32]. The higher value relative to $\mathrm{Ga}(\mathrm{NOTA})$ could be partially ascribed to the higher overall basicity of NOA2P relative to NOTA due to the presence of the two methylenephosphonate groups. The size of the triaza macrocyclic ring matches that of the $\mathrm{Ga}^{3+}$ ion $(\mathrm{r}=0.68 \AA)$ quite well, but, as the ring occupies only one facial plane of the coordination octahedron, such a matching might play a minor role in complex stability. The ability of $\mathrm{Ga}^{3+}$ to promote the distortion of the macrocyclic ring to allow the pendant groups to come to the ideal structural proximity to the metal centre for bond formation could be the determining factor in stabilizing the complex. As the phosphonate ligands are more rigid than the carboxylate ones, as shown by NMR (see later), they can more easily adopt a pre-organized conformation favourable to bond formation, leading to an entropic contribution to the stability of the $\mathrm{Ga}(\mathrm{NOA} 2 \mathrm{P})^{2-}$ complex. In the case of Ga(DOTA), stability decreases due to a larger macrocyclic ring and the presence of two free carboxylate groups [32].

The stability sequence of the NOTA analogues based just on their resistance against the formation of $\mathrm{Ga}(\mathrm{OH})_{4}^{-}$, as followed by ${ }^{71} \mathrm{Ga} \mathrm{NMR}$, will be discussed below.

Three protonation steps were found for the Ga(NOA2P) $)^{2-}$ complex, the first two corresponding to protonation of the negatively charged metal-unbound oxygen atoms of the two coordinated phosphonate groups, while the third one probably results from protonation of the carboxylate. Despite the tendency of $\mathrm{Ga}^{3+}$ to form hydroxocomplexes, two mixed hydroxocomplexes were considered in the potentiometric model. In these hydroxospecies, the hydroxide anion probably replaces one or two of the coordinated pendant arms. An hydroxo complex was previously proposed for Ga(NOTA) [19] but not for Ga(DOTA) [32]. 
As it is difficult to compare the stability constants of different $\mathrm{Ga}^{3+}$ chelators due to differences in ligand $\mathrm{pK}_{\mathrm{a}}$ and/or stoichiometry, the $\mathrm{pGa}$ value has been proposed as a means for more direct comparison. The pGa values express the amount of free $\mathrm{Ga}^{3+}$ present at equilibrium at a total ligand concentration of $10^{-5} \mathrm{M}$, a total Ga concentration of $10^{-6} \mathrm{M}$, and $\mathrm{pH}$ 7.4. $\mathrm{A} \mathrm{pGa}=26.60$ was calculated for $\mathrm{Ga}(\mathrm{NOA} 2 \mathrm{P})$ from our thermodynamic data in Table 2, which is higher than that of $\mathrm{Ga}(\mathrm{NOTA})(\mathrm{pGa}=24.81)$ and specially of $\mathrm{Ga}(\mathrm{DOTA})(\mathrm{pGa}=20.19)$, indicating that NOA2P is the strongest chelator.

2.2. NMR studies of the complexes. In order to validate the speciation model of the $\mathrm{Ga}^{3+}$ NOA2P $-\mathrm{H}^{+}$ternary system based on potentiometry, we have carried out ${ }^{31} \mathrm{P}$ and ${ }^{69} \mathrm{Ga}(\mathrm{I}=$ 3/2, $60.4 \%$ natural abundance, quadrupole moment $\left.\mathrm{Q}=+17.8 \mathrm{fm}^{2}\left(1 \mathrm{fm}=10^{-15} \mathrm{~m}\right)[33]\right)$ NMR measurements in strongly alkaline samples (Fig. 4). In fact, the following reaction has been followed:

$\mathrm{Ga}(\mathrm{NOA} 2 \mathrm{P})(\mathrm{OH})^{3-}+2 \mathrm{OH}^{-}+\mathrm{H}_{2} \mathrm{O} \rightleftharpoons \mathrm{Ga}(\mathrm{OH})_{4}^{-}+\mathrm{HNOA}^{-} \mathrm{P}^{4-}$

The free ligand (NOA2 $\mathrm{P}^{5-}$ dominantly in monoprotonated form) gives a (proton coupled) ${ }^{31} \mathrm{P}$ NMR triplet signal at $10.9 \mathrm{ppm}$, while the $\mathrm{Ga}(\mathrm{NOA} 2 \mathrm{P})(\mathrm{OH})^{3-}$ shows two partially overlapping signals at 11.45 and $11.60 \mathrm{ppm}$. Despite the limited resolution, one can clearly conclude the non-equivalence of the two coordinated phosphonate groups in the $\mathrm{Ga}(\mathrm{NOA} 2 \mathrm{P}(\mathrm{OH}))^{3-}$ complex. The ${ }^{69} \mathrm{Ga}$ NMR spectra are in full agreement with the ${ }^{31} \mathrm{P}$ NMR results, and although the signal of $\mathrm{Ga}(\mathrm{NOA} 2 \mathrm{P})(\mathrm{OH})^{3-}$ at about $120 \mathrm{ppm}$ is too broad for quantitative integration, the sharp signal of $\mathrm{Ga}(\mathrm{OH})_{4}^{-}$at $220 \mathrm{ppm}$ gives reliable intensity data for calculation of the molar ratios. Fig. 5 shows the distribution curves calculated by the potentiometric model together with the concentrations of the species measured by multinuclear NMR. The coincidences are in general very good, with a small systematic deviation at the highest $\mathrm{pH}$ values. 
The behaviour in aqueous solution of the $\mathrm{Ga}^{3+}$ complexes of the three phosphonatecontaining ligands, $\mathrm{NOTP}^{6-}, \mathrm{NO}^{2} \mathrm{AP}^{4-}$ and $\mathrm{NOA}_{2} \mathrm{P}^{5-}$ (Fig. 1) was further studied by ${ }^{69 / 71} \mathrm{Ga}$, ${ }^{31} \mathrm{P},{ }^{13} \mathrm{C}$ and ${ }^{1} \mathrm{H}$ multinuclear NMR spectroscopy. Table 3 summarises the observed ${ }^{71} \mathrm{Ga}(\mathrm{I}$ $=3 / 2,39.6 \%$ natural abundance, quadrupole moment $\left.\mathrm{Q}=11.2 \mathrm{fm}^{2}[33]\right) \mathrm{NMR}$ data obtained for these systems, together with that previously reported for other triaza macrocyclic ligand complexes. In our previous studies with $\mathrm{Ga}(\mathrm{NOTP})^{3-}$ a ${ }^{71} \mathrm{Ga}$ NMR signal was detected at $110 \mathrm{ppm}\left(\Delta v_{1 / 2}=434 \mathrm{~Hz}\right)$ and the chelate was found to be stable towards acid and base catalysed hydrolysis in the $\mathrm{pH}$ range $2-8$ [20]. In this $\mathrm{pH}$ interval, the signal of the $\mathrm{Ga}^{3+}$ aqua-ion was not observed. At $\mathrm{pH}$ above 8 , the signal of $\mathrm{Ga}(\mathrm{OH})_{4}^{-}(\delta$ $=222 \mathrm{ppm}$ ) could be detected, whereas its carboxylate analogue Ga(NOTA) only shows formation of tetrahydroxogallate above $\mathrm{pH} 10$ and has a wider $\mathrm{pH}$ range of stability $(\mathrm{pH} 0.7$ to 12) $[11,12]$. The different stabilities of the NOTP $^{6-}$ and NOTA $^{3-}$ chelates against hydroxide attack might arise from a more open bite angle $\mathrm{N}-\mathrm{Ga}-\mathrm{O}$, due to larger $\mathrm{P}-\mathrm{C}$ and $\mathrm{P}-$ O bonds in the former than C-O and C-N in the later [20].

The ${ }^{71} \mathrm{Ga}$ NMR shifts of Ga(NOTA) (171 ppm), Ga(NO2AP) ${ }^{-}(153 \mathrm{ppm}), \mathrm{Ga}(\mathrm{NOA} 2 \mathrm{P})^{2-}$ $(130 \mathrm{ppm})$ and $\mathrm{Ga}(\mathrm{NOTP})^{3-}(110 \mathrm{ppm})$ show an almost linear variation with the number of phosphonate binding groups, which have an additive effect on the ${ }^{71} \mathrm{Ga}$ shifts. Upon successive substitutions of carboxylate groups by phosphonate groups in Ga(NOTA), the ${ }^{71} \mathrm{Ga}$ shift decreases by similar amounts $(28,23$ and $20 \mathrm{ppm})$, in agreement with empirical predictions based on the dependence of ${ }^{71} \mathrm{Ga}$ shifts on the type and number of coordinated pendant groups (carboxylate > phosphinate ester $>$ phosphonate [20]). These effects are much larger than those observed in triaza macrocyclic chelates where the $\mathrm{Ga}^{3+}$ coordination changes from $\mathrm{N}_{2} \mathrm{O}_{3}$ to $\mathrm{N}_{4} \mathrm{O}_{2}$ [25]. Such a reduction (although smaller) of the metal nucleus 
shift upon replacement of carboxylate coordination by phosphonate coordination is also observed for ${ }^{27} \mathrm{Al}$ NMR shifts, as exemplified by Al(NOTA) and Al(NOTP) ${ }^{3-}$ (Table 3).

The ${ }^{71} \mathrm{Ga}$ shifts of the $\mathrm{Ga}^{3+}$ chelates are almost constant for $\mathrm{pH} 5-10$, where the unprotonated complexes predominate (data not shown). However, the formation of protonated forms at lower $\mathrm{pH}$ values and of the hydroxo complexes at $\mathrm{pH}>10$, significantly affect the shifts.

The linewidth of the ${ }^{71} \mathrm{Ga}$ NMR resonance is very sensitive to the symmetry of the $\mathrm{Ga}^{3+}$ coordination sphere. The signals of $\mathrm{Ga}(\mathrm{NO} 2 \mathrm{AP})^{-}$and $\mathrm{Ga}(\mathrm{NOA} 2 \mathrm{P})^{2-}$ are much broader than those found previously for $\mathrm{Ga}(\mathrm{NOTP})^{3-}$ [20] and specially for $\mathrm{Ga}(\mathrm{NOTA})$ [11, 12], reflecting a more distorted octahedral geometry. Ga(NOTA) has a highly symmetric crystal structure, with $\mathrm{Ga}^{3+}$ in a slightly distorted octahedral coordination polyhedron, with two opposite almost parallel faces $\mathrm{N}_{3}$ (formed by the three ring nitrogen atoms) and $\mathrm{O}_{3}$ (from the pendant carboxylate oxygen atoms) [11, 12]. The degree of distortion of this coordination polyhedron from a regular octahedron is defined by the twist angle $\theta$ between the $\mathrm{N}_{3}$ and $\mathrm{O}_{3}$ planes from the symmetrical staggered conformation, which can be estimated to be higher in the phosphonate complexes than for $\operatorname{Ga}($ NOTA $)\left(\theta=12.4^{\circ}\right)[11,12]$. The ${ }^{71} \mathrm{Ga}$ NMR signal linewidth is determined by quadrupolar relaxation, which increases with the electric field gradients caused by distortion of the $\mathrm{Ga}^{3+}$ coordination polyhedron. Thus, for complexes with approximately the same size (same rotational correlation time), the ${ }^{71} \mathrm{Ga}$ linewidths are a sensitive measure of the degree of distortion of the complexes in solution. The ${ }^{71} \mathrm{Ga}$ NMR linewidths available for a series of $\mathrm{Ga}^{3+}$ chelates of different triaza macrocycles suggest the following sequence for the degree of distortion in relation to a perfect octahedral geometry: Ga(NOTA) Ga(NODASA) Ga(NOTMP) < Ga(NOTP) < $\mathrm{Ga}(\mathrm{NOTPP})<\mathrm{Ga}(\mathrm{NO} 2 \mathrm{AP})<\mathrm{Ga}(\mathrm{NOTBzP})<\mathrm{Ga}(\mathrm{NOA} 2 \mathrm{P})<\mathrm{Ga}($ DETA $)<<\mathrm{Ga}($ DOTRA $)$ 
$\ll \mathrm{Ga}(\mathrm{UNTA})[20]$. The presence of bonds with different lengths in the case of $\mathrm{Ga}(\mathrm{NOA} 2 \mathrm{P})^{2-}$ and $\mathrm{Ga}(\mathrm{NO} 2 \mathrm{AP})^{-}$(P-O longer than $\mathrm{C}-\mathrm{O}$ ) contributes to the symmetry distortion of the $\mathrm{Ga}^{3+}$ coordination polyhedron in these chelates and thus to the increase of the quadrupolar relaxation and concomitant signal broadening.

The ${ }^{31} \mathrm{P}$ NMR spectra of $\mathrm{Ga}(\mathrm{NO} 2 \mathrm{AP})^{-}$and $\mathrm{Ga}(\mathrm{NOA} 2 \mathrm{P})^{2-}$ in aqueous solution exhibit only one signal in the $\mathrm{pH}$ range $2-10$, with shifts at $\mathrm{pH} 7.0$ of 13.80 and $14.90 \mathrm{ppm}$, respectively, which are lower than the value of $18.00 \mathrm{ppm}$ reported for $\mathrm{Ga}(\mathrm{NOTP})^{3-}$ at the same $\mathrm{pH}$ [22]. The ligands with more than one phosphonate group form $\mathrm{Ga}^{3+}$ complexes with magnetically equivalent bound phosphonates. Below $\mathrm{pH} 4$, the ${ }^{31} \mathrm{P}$ chemical shift increases as protonation of the non-coordinated negatively charged oxygen atoms of the metal-coordinated phosphonate groups occurs, in accordance with previous studies [22, 26]. Above $\mathrm{pH}$ 10-12, the NMR signal of the free ligand also starts to appear (Fig. 7).

The ${ }^{1} \mathrm{H},{ }^{13} \mathrm{C}$ and $2 \mathrm{D}$ NMR spectra of $\mathrm{Ga}(\mathrm{NOA} 2 \mathrm{P}){ }^{2-}$, as well as the $1 \mathrm{D}{ }^{1} \mathrm{H}$ spectrum of $\mathrm{Ga}\left(\mathrm{NO}_{2} \mathrm{AP}\right)^{-}$at $\mathrm{pH} 7$ are shown in Figures $\mathrm{S} 8, \mathrm{~S} 9$ and $\mathrm{S} 10$, and should be compared with those of $\mathrm{Ga}(\mathrm{NOTP})^{3-}$ and $\mathrm{Ga}(\mathrm{NOTA})$ from the literature $[11,12,20]$. Their detailed analysis is described in the SI. Here only the main conclusions are highlighted. The type of proton spectrum obtained for these complexes depends on the NMR timescale of their internal conformational rearrangements, namely the concerted $(\lambda \lambda \lambda) \leftrightarrow(\delta \delta \delta)$ conformational interconversions of the ethylene diamine protons in the five-membered chelates of the triaza ring, and the concerted interconversion of the three pendant arms between $\Delta$ and $\Lambda$ configurations in the distorted coordination octahedron. Those processes have been found to be slow for $\mathrm{Ga}(\mathrm{NOTP})^{3-}$, with quite rigid macrocyclic rings [20], in 
contrast with Ga(NOTA), with fast conformational exchange of the flexible ring. $[11,12,15]$.

The ${ }^{1} \mathrm{H}$ NMR spectrum of Ga(NOA2P) ${ }^{2-}$ displays a complex pattern of signals (Fig. S8), reflecting a rigid complex with inert metal-ligand bonds. The internal conformational interconversions are slow on the NMR time scale, with no equivalence between the protons in axial and equatorial positions above and below the ring N3 plane. The two acetate protons form a sharp $\mathrm{AB}$ pattern, while the four phosphonate protons originate an $\mathrm{ABX}$ system due to coupling to $\mathrm{X}={ }^{31} \mathrm{P}$. All the ring protons are magnetically non-equivalent, leading to twelve different multiplets. The rigidity of the arms and ring of the complex is confirmed by its proton-decoupled ${ }^{13} \mathrm{C}$ NMR spectrum (Fig. S8B). The acetate pendant arm originates a singlet for the $\mathrm{C}_{7,8}$ methylene carbon, while the two equivalent $\mathrm{C}_{7,8}$ methylenephosphonate carbons resonate as a doublet due to geminal coupling to ${ }^{31} \mathrm{P}$. The six ring carbons are all magnetically non-equivalent. Of those, the four located next to the two phosphonate arms $\left(\mathrm{C}_{25 \mathrm{u}}, \mathrm{C}_{36 \mathrm{~d}}, \mathrm{C}^{\prime}{ }_{36 \mathrm{u}}\right.$ and $\left.\mathrm{C}^{\prime}{ }_{25 \mathrm{~d}}\right)$ can be distinguished by their different two-bond ${ }^{13} \mathrm{C}_{-}{ }^{31} \mathrm{P}$ coupling constants. Those located above the N3 plane $\left(\mathrm{C}_{25 \mathrm{u}}\right.$ and $\left.\left.\mathrm{C}^{\prime}{ }_{36 u}\right)\right)$ are doublets, with ${ }^{2} J_{\mathrm{PC}}=14 \mathrm{~Hz}$, due to $\mathrm{P}-\mathrm{C}-\mathrm{N}-\mathrm{C}_{\mathrm{u}}$ dihedral angles close to $180^{\circ}$. Those below that plane $\left(\mathrm{C}_{36 \mathrm{~d}}\right.$ and $\left.\mathrm{C}^{\prime}{ }_{25 \mathrm{~d}}\right)$ are singlets, since the $\mathrm{P}-\mathrm{C}-\mathrm{N}-\mathrm{C}_{\mathrm{d}}$ dihedral angles are close to $90^{\circ}$ and the coupling is too small to be observed $\left({ }^{2} J_{\mathrm{PC}}<1 \mathrm{~Hz}\right)[16,36]$. The other two carbons $\left(\mathrm{C}_{14 \mathrm{~d}}\right.$ and $\left.\mathrm{C}^{\prime}{ }_{14 \mathrm{u}}\right)$ are also singlets, due to their distance from the ${ }^{31} \mathrm{P}$ nuclei $\left({ }^{4} J_{\mathrm{PC}}<1\right.$ $\mathrm{Hz})$.

The ${ }^{1} \mathrm{H}$ NMR spectrum of $\mathrm{Ga}(\mathrm{NO} 2 \mathrm{AP})^{-}$(Fig. S10) shows an AB pattern for the four acetate protons and an ABX multiplet for the two methylenephosphonate protons, with broad resonances for the twelve macrocyclic ring protons, indicating that the $(\lambda \lambda \lambda) \leftrightarrow(\delta \delta \delta)$ 
conformational interconversions of the ring $\mathrm{NCH}_{2} \mathrm{CH}_{2} \mathrm{~N}$ protons are fast on the ${ }^{1} \mathrm{H}$ NMR time scale.

Thus, from the analysis of the NMR data available, it can be concluded that the presence of an increasing number of phosphonate groups in these $\mathrm{Ga}^{3+}$ complexes rigidifies their structure, a similar effect to what has been observed for $\operatorname{Ln}(\mathrm{DOTA}), \operatorname{Ln}(\mathrm{DO} 2 \mathrm{~A} 2 \mathrm{P})$ and $\operatorname{Ln}(\mathrm{DOTP})$ complexes [36-39].

\subsection{In vivo studies}

The properties of the two structurally related radio-chelates $\left[{ }^{67} \mathrm{Ga}\right](\mathrm{NO} 2 \mathrm{AP})^{-}$and $\left[{ }^{67} \mathrm{Ga}\right](\mathrm{NOA} 2 \mathrm{P})^{2-}$ were evaluated in Wistar rats in vivo aiming at the elucidation of structure-activity relationships determinant for biodistribution and clearance from the body. The scintigraphic images obtained 30 minutes after injection of the ${ }^{67} \mathrm{Ga}^{3+}$-labeled chelates are shown in Fig. S11. Both chelates show activity in the bladder and in the kidneys significantly higher than the background. Fig. S12 shows the averaged time-activity curves, obtained from dynamic acquisitions for regions of interest (ROI) in the kidneys and liver. The values of mean activity/pixel for each ROI, after background subtraction, stated as the thorax activity, have been used to obtain regional time-activity curves that were further normalized to the maximum activity obtained for each chelate. The imaging data confirm that both radio-chelates undergo renal excretion, as expected for highly charged species. The renal excretion curves for the two ${ }^{67} \mathrm{Ga}^{3+}$ chelates are very similar indicating that the presence of an extra negative charge for $\left[{ }^{67} \mathrm{Ga}\right](\mathrm{NOA} 2 \mathrm{P})^{2-}$ does not change much its renal excretion profile. Furthermore, none of the chelates seems to be retained for a long time in the kidneys as the decrease of activity with time reveals. In a previous study, the structurally related $\left[{ }^{67} \mathrm{Ga}\right](\mathrm{NOTA}),\left[{ }^{67} \mathrm{Ga}\right](\mathrm{NOTPME})$ and $\left.\left[{ }^{67} \mathrm{Ga}\right](\mathrm{NOTP})\right)^{3-}$ chelates were 
found to undergo renal excretion, with a much longer kidney retention time for the high negatively charged $(-3)$ chelate $\left[{ }^{67} \mathrm{Ga}\right](\mathrm{NOTP})^{3-}$ than the neutral ones [22].

Fig. 6 shows the biodistribution results for the two radio-gallium chelates $2 \mathrm{~h}$ after injection. The activity is presented as percentage of the injected activity per gram of organ $(\% \mathrm{ID} / \mathrm{g})$. These results show that the main activity is located in the kidneys, which is in good agreement with the scintigraphic imaging data. The percent kidney activity retained at 2h for the two chelates with (-1) and (-2) charge is higher than the values observed in the same conditions for the neutral chelates $\left[{ }^{67} \mathrm{Ga}\right](\mathrm{NOTA})$ and ${ }^{67} \mathrm{Ga}(\mathrm{NOTPME})$, but lower than for the $(-3)$ charged $\left[{ }^{67} \mathrm{Ga}\right](\mathrm{NOTP}){ }^{3-}$ chelate [22], indicating a positive correlation of chelate negative charge with its kidney retention. The activity measured for the other organs is negligible, particularly for the brain. The absence of activity in the brain indicates that these chelates are unable to cross the blood brain barrier, as expected for charged hydrophilic compounds. [40]

These results demonstrate the high in vivo stability of these two ${ }^{67} \mathrm{Ga}^{3+}$ chelates. Their dissociation would lead to the accumulation of the radio-metal in iron sites, such as transferrin, which accumulates in the bone marrow. [41] This is in agreement with the much higher conditional stability of $\mathrm{Ga}(\mathrm{NOA} 2 \mathrm{P})^{2-}$ relative to Ga-Transferrin $\left(\mathrm{Ga}_{2} \mathrm{Tf}\right)$. [42] Such a comparison is best done by comparing calculated pGa values (values of free $\mathrm{Ga}^{3+}$ computed for a $1 \mu \mathrm{M} \mathrm{Ga}^{3+}$ and $10 \mu \mathrm{M}$ ligand solution at $\mathrm{pH}$ 7.4). Pecoraro reports the values of the two conditional stability constants (at $27 \mathrm{mM} \mathrm{NaHCO}_{3}$ and $\mathrm{pH}$ 7.4) for $\mathrm{Ga}^{3+}$ binding to transferrin, $\log K^{*_{1}}=20.3$ and $\log K^{*}{ }_{2}=19.3$, with the corresponding $\mathrm{pGa}$ values (of 21.3 and 20.3). Using the stability data of Table 2 a much larger value of $\mathrm{pGa}=$ 26.60 for $\mathrm{Ga}(\mathrm{NOA} 2 \mathrm{P})$ can be calculated (assuming no $\mathrm{NaHCO}_{3}$ effect), also larger than for 
$\mathrm{Ga}(\mathrm{NOTA})(\mathrm{pGa}=24.81)$, and specially $\mathrm{Ga}(\mathrm{DOTA})(\mathrm{pGa}=20.19)[19,32]$. In addition, chelate decomposition would lead to formation of gallium hydroxide colloids that would be trapped by the liver and spleen macrophages. These processes would originate considerable background activity during longer periods and slower excretion. The biodistribution data obtained $48 \mathrm{~h}$ after injection (data not shown) reinforces this conclusion, as there is virtually no activity located in the bones or at the liver-spleen level.

\section{Conclusions}

The protonation of the triaza macrocyclic ligands $\mathrm{NOTP}^{6-}, \mathrm{NO}_{2} \mathrm{AP}^{4-}$ and $\mathrm{NOA}_{2} \mathrm{P}^{5-}$ and their complexation by $\mathrm{Ga}^{3+}$ were investigated by potentiometry and multinuclear $\left({ }^{1} \mathrm{H},{ }^{31} \mathrm{P}\right.$, ${ }^{13} \mathrm{C}$ and ${ }^{69 / 71} \mathrm{Ga}$ ) NMR spectroscopy and were compared with previous results with NOTA ${ }^{3-}$ and NOTP ${ }^{6-}$. We determined the ligand stepwise protonation constants by NMR, including the very high first one $\left(\log K_{\mathrm{LH} 1}>14\right)$ for $\mathrm{NOTP}^{6-}$ and $\mathrm{NO}_{2} \mathrm{AP}^{4-}$, which is outside the range of potentiometry. The high basicity of the chelators contributes to the slow formation kinetics of their $\mathrm{Ga}^{3+}$ chelates and the slow ${ }^{67 / 68} \mathrm{Ga}$ radiolabeling, requiring heating at $95{ }^{\circ} \mathrm{C}$ for 30 minutes. It has been previously proposed that during the formation of chelates with this kind of macrocycles the rigid ring acts simply as a frame, constraining the pendant arms of the ligand (either acetate or methylenephosphonate) to a rather rigid position, favourable for coordinating the $\mathrm{M}^{3+}$ ions [37]. All the studied chelates have shown a remarkable thermodynamic and kinetic stability in solution. However, their structural internal dynamics were found to be different. The higher rigidity of the $\mathrm{NOTP}^{6-}$ chelate was particularly evident when compared with the NOTA ${ }^{3-}$ chelate, which lead to the nonequivalence of all the ring protons in the former complex. The NOA2 ${ }^{5-}$ chelate shows a similar rigidity to the $\mathrm{NOTP}^{6-}$ chelate, whereas the macrocyclic ring in the $\mathrm{NO}^{2} \mathrm{AP}^{4-}$ chelate is as flexible as the ring in the NOTA complex. Thus, from the present studies of this series 
of $\mathrm{Ga}^{3+}$ complexes, we observed a rigidifying effect of an increasing number of phosphonate groups on the ligand structure.

In addition to their own steric requirements, the conformational characteristics of the macrocyclic ring in the chelated ligands are largely determined by the ionic radius of the metal ion. From this and other studies, the high preference of the triaza macrocycles for the $\mathrm{Ga}^{3+}$-ion is evident, a fact of great importance in the biomedical applications of these type of chelates. This is illustrated by the remarkably high thermodynamic stability constant of the $\mathrm{Ga}(\mathrm{NOA} 2 \mathrm{P})^{2-}$ complex $\left(\log K_{\mathrm{GaL}}=34.44\right)$, which was determined by a method based on the combined use of potentiometry and ${ }^{69} \mathrm{Ga}$ and ${ }^{31} \mathrm{P} \mathrm{NMR}$, as a case study. Its conditional stability at $\mathrm{pH} 7.4$ is still considerably higher than the $\mathrm{Ga}^{3+}$-transferrin complex. The $\mathrm{Ga}(\mathrm{NOA} 2 \mathrm{P})^{2-}$ chelate is also more stable than $\mathrm{Ga}(\mathrm{NOTA})$ and $\mathrm{Ga}(\mathrm{DOTA})^{-}$chelates, frequently used in bioconjugation.

The multinuclear NMR data obtained for the GaL chelates allowed to obtain new insights into their conformational dynamics, in particular, the rigidifying effect of phosphonate vs. carboxylate $\mathrm{Ga}^{3+}$ chelation.

The in vivo behaviour of the radiochelates ${ }^{67} \mathrm{Ga}(\mathrm{NO} 2 \mathrm{AP})^{-}$and ${ }^{67} \mathrm{Ga}(\mathrm{NOA} 2 \mathrm{P})^{2-}$ in Wistar rats, as studied by gamma-imaging and biodistribution, proved their high in vivo stability and rapid renal excretion. Our studies also demonstrated how the biodistribution profile of small chelates can be tuned by the overall chelate charge, as the renal retention of the chelates increases with their negative charge.

In conclusion, the presence of phosphonate binding groups increases the thermodynamic stability and rigidity of the $\mathrm{Ga}^{3+}$ triaza macrocyclic chelates, which are important features to take into account in the optimized design of ${ }^{67 / 68} \mathrm{Ga}$-radiolabeled bioconjugates for nuclear imaging. For instance, the single acetate arm of NOA2P could be conjugated to the 
terminal amino group of a peptide, as shown before for Ga(NOTA)-RGD conjugates [24]. $\mathrm{Ga}^{3+}$-NODAGA analogues, similar to $\mathrm{Ga}^{3+}$-NODAGATOC, [43] with two methylenephospho(i)nate arms and the carboxylate group conjugated to a peptide, such as a c-RGD or an octreotide, could also be envisaged in future work

\section{Experimental section}

\subsection{Materials}

The ligands $\mathrm{H}_{6} \mathrm{NOTP}$ [26,44], $\mathrm{H}_{4} \mathrm{NO} 2 \mathrm{AP}$ and $\mathrm{H}_{5} \mathrm{NOA} 2 \mathrm{P}$ [45] were synthesised according to the literature. The purity of these ligands was checked by ${ }^{1} \mathrm{H}$ NMR spectroscopy, and their chemical shifts were in agreement with the values reported in the literature $[26,44,45]$. $\left[{ }^{67} \mathrm{Ga}\right]$ (citrate) was purchased from CIS-BIO (Gif-sur-Yvette, France). All the other reagents and solvents were of analytical grade and were purchased from Sigma-Aldrich and were used without further purification.

\subsection{Potentiometry}

The potentiometric titrations were carried out with a Metrohm 702SM Titrino titration workstation with the use of a Metrohm-6.0233.100 combined electrode. The titrated solutions $\left(6-10 \mathrm{~mL}\right.$ in total) were thermostated at $25 \pm 0.1{ }^{\circ} \mathrm{C}$. The samples were magnetically stirred and $\mathrm{N}_{2}$ gas was bubbled through the solutions before and during the procedure to avoid any interaction with air. The titrations were performed in the $\mathrm{pH}$ range of 12.35-2.04 (see Fig. 2). The ionic medium was $0.1 \mathrm{M} \mathrm{KCl}$. The pH-electrode was calibrated using standard KH-phthalate $(\mathrm{pH}=4.005)$ and borax $(\mathrm{pH}=9.177)$ buffers. The $\mathrm{H}^{+}$concentrations were calculated from the measured $\mathrm{pH}$ values according to the method proposed by Irving et al. [46]. 
The concentration of the $\mathrm{H}_{5} \mathrm{NOA} 2 \mathrm{P}$ ligand was determined by pH-potentiometry from the difference of the titration curves obtained in the absence and presence of 50-fold excess of $\mathrm{Ca}^{2+}$ (Fig. S1). The difference in the inflection points of the two titration curves corresponds to three equivalents of the ligand. The protonation constants of NOA2 $\mathrm{P}^{5-}$ were determined in $0.1 \mathrm{M} \mathrm{KCl}$ and were calculated from the potentiometric data obtained by titration of $6.00 \mathrm{~mL}$ solution containing of $4.715 \mathrm{mM}$ ligand with a standardized carbonatefree $0.1937 \mathrm{M} \mathrm{KOH}$ in the $\mathrm{pH}$ range 1.78-11.92. The titrations of the $\mathrm{Ga}^{3+}$ complex of NOA2 $\mathrm{P}^{5-}$ were performed with $4 \mathrm{mM}$ ligand solutions containing 1 equivalent of the metal cation from $\mathrm{pH} 12.35$ to 2.04 , with maximum 5 min waiting between two consecutive titration points to get constant potential. The equilibrium constants were calculated from at least two parallel titrations with the program PSEQUAD [47]. The whole curve was fitted simultaneously and the equilibrium constants of the $\mathrm{GaL}(\mathrm{OH})_{2}, \mathrm{GaL}(\mathrm{OH}), \mathrm{GaL}$ and protonated species $(\mathrm{L}=\mathrm{NOA} 2 \mathrm{P})$ were evaluated form the titration data. The titrated sample was back titrated with base solution and the obtained curve (strong acid-base-like titration curve) suggests a slow equilibration process in this direction. Only mononuclear $\mathrm{Ga}^{3+}$-species were found. Fixed values were used for the ionic product of water at $25^{\circ} \mathrm{C}$ and $0.1 \mathrm{M}$ ionic strength (determined by independent titration to be $\mathrm{pK}_{\mathrm{w}}=13.89$ ), ligand acidity constants, the hydrolysis constants of $\mathrm{Ga}(\mathrm{OH})_{\mathrm{n}}{ }^{+3-\mathrm{n}}$ species $(\mathrm{n}=1-4)[48]$ and total concentrations of metal, ligand and acid. All values and errors (one standard deviation) reported are at least the average of two consistent and independent experiments.

\subsection{NMR studies}

The NMR spectra were obtained on a Bruker Avance II 400 spectrometer operating at $400.13\left({ }^{1} \mathrm{H}\right), 121.99\left({ }^{71} \mathrm{Ga}\right), 161.97\left({ }^{31} \mathrm{P}\right)$ and $100.610\left({ }^{13} \mathrm{C}\right) \mathrm{MHz}$, a Bruker AVANCE I 360 
spectrometer operating at $360.13\left({ }^{1} \mathrm{H}\right), 86.43\left({ }^{69} \mathrm{Ga}\right.$, tuning the ${ }^{13} \mathrm{C}$ channel of a QNP probe to the given frequency) and $145.78 \mathrm{MHz}\left({ }^{31} \mathrm{P}\right.$, the advantage of this experimental setup was, that ${ }^{69} \mathrm{Ga}$ and ${ }^{31} \mathrm{P}$ spectra could be measured with the same probe on the same samples just changing between the ${ }^{13} \mathrm{C}$ and ${ }^{31} \mathrm{P}$ channels); and a Varian Unity-500 spectrometer operating at $499.84\left({ }^{1} \mathrm{H}\right), 202.34\left({ }^{31} \mathrm{P}\right)$ and $152.40 \mathrm{MHz}\left({ }^{71} \mathrm{Ga}\right)$. The chemical shifts are reported in ppm, relative to the external references tetramethylsilane (TMS) for ${ }^{1} \mathrm{H}, \mathrm{H}_{3} \mathrm{PO}_{4}$ $(85 \% v / v)$ in $\mathrm{D}_{2} \mathrm{O}$ for ${ }^{31} \mathrm{P}$ and the signal of $0.1 \mathrm{M}\left[\mathrm{Ga}\left(\mathrm{H}_{2} \mathrm{O}\right)_{6}\right]^{3+}$ in a solution of gallium nitrate in water containing $0.1 \mathrm{M} \mathrm{HNO}_{3}$ and $10 \% \mathrm{D}_{2} \mathrm{O}$ for ${ }^{69 / 71} \mathrm{Ga}$, respectively. ${ }^{31} \mathrm{P}$ and ${ }^{13} \mathrm{C}$ NMR spectra were measured with broad-band proton decoupling except for several spectra with no decoupling indicated in the text. The ${ }^{1} \mathrm{H}$ and ${ }^{13} \mathrm{C}$ NMR spectra were only partially assigned using the two-dimensional COSY, ${ }^{1} \mathrm{H}_{-}{ }^{13} \mathrm{C}$ HSQC and ${ }^{1} \mathrm{H}_{-}{ }^{13} \mathrm{C}$ HMBC techniques. The spectra were obtained in the temperature range of 20 to $80{ }^{\circ} \mathrm{C}$ and in the $\mathrm{pH}$ range of 0.5 to 13 . Some ${ }^{1} \mathrm{H}$ and ${ }^{31} \mathrm{P}$ NMR were recorded in highly alkaline solutions of $1-10 \mathrm{M}$ $\mathrm{KOH}$ (i.e. out of range of the $\mathrm{pH}$ concept), where the $\mathrm{pH}=14+\log \mathrm{C}_{\mathrm{KOH}}$. The experiments at variable temperature were run with a precision of $\pm 0.5^{\circ} \mathrm{C}$.

The solutions of the ligands NOA2P, NO2AP and NOTP (10 mM) for ${ }^{1} \mathrm{H}$ NMR pH titrations were prepared in $\mathrm{D}_{2} \mathrm{O}(99.8 \%)$ and the $\mathrm{pD}$ was adjusted with $\mathrm{DCl}$ and $\mathrm{CO}_{2}$-free NaOD solutions. The final $\mathrm{pH}$ was determined with a Hanna $8417 \mathrm{pH}$ meter fitted with a combined Hanna H11310 electrode. For the $\mathrm{D}_{2} \mathrm{O}$ solutions, the measured $\mathrm{pH}$ value was corrected for the deuterium isotope effect according to $\mathrm{pH}=\mathrm{pD}-0.40$. [49]

The first $\mathrm{p} K_{\mathrm{a}}$ values of NOA2P and NOTP were determined at $25^{\circ} \mathrm{C}$ by ${ }^{31} \mathrm{P} \mathrm{NMR}$. The $\mathrm{pH}$ was adjusted by addition of $\mathrm{cc} . \mathrm{HCl}$ and/or cc. $\mathrm{KOH}$ solution. Separate $10 \mathrm{mM}$ solutions in water were prepared in the $\mathrm{pH}$ range of $12.2-15$ and an insert capillary with $5 \mu \mathrm{l}$ 
phosphoric acid and $495 \mu \mathrm{D}_{2} \mathrm{O}$ as an external reference and for locking. The $\mathrm{p} K_{\mathrm{a}}$ values were calculated by least square fitting of the experimental $\mathrm{pH}$-chemical shift data pairs of the titration curves using the program Scientist.

The speciation model based on $\mathrm{pH}$-potentiometry for $\mathrm{Ga}^{3+}-\mathrm{NOA} 2 \mathrm{P}^{5-}-\mathrm{H}^{+}$was also checked using ${ }^{69} \mathrm{Ga}$ and ${ }^{31} \mathrm{P}$ NMR. For this purpose, a linear calibration relationship was obtained between the measured intensity of the ${ }^{69} \mathrm{Ga}$ NMR signal of the $\mathrm{Ga}(\mathrm{OH})_{4}{ }^{-}$species present in a series of gallium nitrate aqueous solutions at $\mathrm{pH} 13$ and concentrations in the 2 - $15 \mathrm{mM}$ range (Fig. S7). Then, a series of $10 \mathrm{mM}$ solutions of the complex were prepared by mixing solutions of ligand and gallium nitrate at 1:1 molar ratio in the $\mathrm{pH}$ range $11.1-$ 13 and the intensities of their ${ }^{69} \mathrm{GaNMR}$ signal of the $\mathrm{Ga}(\mathrm{OH}) 4^{-}$species, as well as the integrals of their ${ }^{31} \mathrm{P}$ NMR signals observed for the Ga(NOA2P) ${ }^{2-}$ complex and free NOA2P ligand were measured, as shown in Fig. S4. The molar fractions of the species were calculated from the NMR intensities and plotted together with the distribution curves in order to visualise the matching of the results from the two independent sets of experiments (Fig. 5).

The ${ }^{1} \mathrm{H},{ }^{31} \mathrm{P}$ and ${ }^{71} \mathrm{Ga}$ NMR studies of the chelates on the Varian U-500 spectrometer were carried out in $\mathrm{D}_{2} \mathrm{O}(99.8 \%)$ at $10 \mathrm{mM}$ concentration by addition of equimolar stock solutions of gallium nitrate and ligand. The $\mathrm{pH}$ of the solutions was adjusted with $\mathrm{DCl}$ and $\mathrm{CO}_{2}$ free $\mathrm{NaOD}$ and measured with a Crison MicropH $2002 \mathrm{pH}$ meter, equipped with an Ingold 405-M5 combined electrode.

\subsection{Imaging and activity counting}

A gamma camera-computer system (Maxicamera Digital GE 400 AC $\gamma$-camera, from General Electric, Milwaukee, WI, USA) was used for acquisition and pre-processing of the 
in vivo gamma images, controlled by a Starport computer. Data processing and display were performed on a personal computer using homemade software developed for the IDL 6.3 (Interactive Data Language, Research Systems, Boulder, CO, USA) computer tool. For measuring the in vitro activity of the organs a DPC-Gamma C12 gamma counter, coupled to a Compaq DeskPro computer was used.

\subsection{In vivo studies}

For the in vivo and in vitro studies the radiochelates were prepared by mixing the ligand solutions in $0.1 \mathrm{M}$ HEPES with $\left[{ }^{67} \mathrm{Ga}\right]\left(\right.$ citrate) and heating at $95{ }^{\circ} \mathrm{C}$ for 30 minutes. The gallium-67 source was gallium citrate. Finally the solution $\mathrm{pH}$ was adjusted to 7 with $\mathrm{NaOH}$. Two groups of three Wistar rats (males) weighing approximately $300 \mathrm{~g}$ (one group for each chelate) were anaesthetized with Ketamine/Diazepam in a 4:1 proportion and injected in the femoral vein with circa $110 \mu \mathrm{Ci}$ of $\left[{ }^{67} \mathrm{Ga}\right](\mathrm{NOA} 2 \mathrm{P}){ }^{2-}$ or $\left[{ }^{67} \mathrm{Ga}\right](\mathrm{NO} 2 \mathrm{~A} 2 \mathrm{P})$. The animals were then positioned in ventral decubitus over the detector. Image acquisition was initiated immediately before radiotracer injection. Sequences of 180 images (of $10 \mathrm{~s}$ each) were acquired to 64 × 64 matrices. Images were subsequently processed using a homemade IDL based program. In order to analyse the transport of radiotracer over time, three regions of interest (ROI) were drawn on the image files, corresponding to the thorax, liver, and left kidney. From these ROI, time-activity curves were obtained. In addition, static data were acquired at 24 and $48 \mathrm{~h}$ after the radiotracer injection.

\subsection{Biodistribution studies.}

Two groups of four anaesthetized animals were injected with circa $110 \mu \mathrm{Ci}$ of each $\left[{ }^{67} \mathrm{Ga}\right]$ chelate. The animals were sacrificed $2 \mathrm{~h}$ and $48 \mathrm{~h}$ after injection and the major organs were collected, weighted and their activity counted in a $\gamma$ well-counter. 


\section{Acknowledgments}

The authors thank the financial support from the Fundação para a Ciência e Tecnologia (F.C.T., Portugal, projects RREQ/481/QUI/2006 and RECI/QEQ-QFI/0168/2012), the Rede Nacional de RMN (RNRMN), the Hungarian Scientific Research Fund (OTKA grants K-109029 and K-120224), the János Bolyai Research Scholarship (Gy.T.) of the Hungarian Academy of Sciences and the EU COST Action TD1004 "Theragnostics Imaging and Therapy". The research was also supported by the EU and co-financed by the European

Regional Development Fund (FEDER) under the projects CENTRO-07-CT62-FEDER) and GINOP-2.3.2-15-2016-00008. 


\section{References}

[1] M.I. Prata, Curr. Radiopharm.1, 5 (2) (2012) 142-9

[2] P. Blower, Dalton Trans. (2006) 1705-11.

[3] S. Liu, Chem. Soc. Rev., 33 (2004) 445-465

[4] F. Rösch, P.J. Riss, Curr Top. Med. Chem. 10 (2010) 1633-1668.

[5] T.J. Waddas, E.H. Wong, G.R. Weisman, C.J. Anderson, Chem. Rev., 110 (2010) 28582902.

[6] M. Fani, J.P. André, H.R. Mäcke, Contrast Media Mol. Imaging, 3 (2008) 67-77.

[7] T.A. Kaden, Pure Appl. Chem. 65 (1993) 1477-1483.

[8] V. Alexander, Chem. Rev. 95 (1995) 273-342.

[9] D.A. Moore, F.E. Fanwick, M.J. Welch, Inorg. Chem. 28 (1989) 1504-1506.

[10] T.W. Duma, F. Marsicano, R.D. Hancock, J. Coord. Chem. 23 (1991) 221-232.

[11] C.J. Broan, J.P.L. Cox, A.S. Craig, R. Kataky, D. Parker, A. Harrison, A.M. Randall, G. Ferguson, J. Chem., Soc., Perkin Trans. 2 (1991) 87-99.

[12] A.S. Craig, D. Parker, H. Adams, N.A. Bailey, Chem. Comm. (1989) 1793-1794.

[13] U. Bossek, D. Hanke, K. Wieghardt, Polyhedron 12 (1993) 1-5.

[14] J.P. André, H.R. Mäcke, M. Zehnder, L. Macko, K.G. Akyel, Chem. Commun. (1998) $1301-1302$

[15] J.P. André, H. Mäcke, A. Kaspar, B. Künnecke, M. Zehnder, L. Macko, J. Inorg. Biochem. 88 (2002) 1-6.

[16] E. Cole, R.C.B. Copley, J.A.K. Howard, D. Parker, G. Ferguson, J.F. Gallagher, B. Kaitner, A. Harrison, L. Royle, J. Chem., Soc., Dalton Trans. (1994) 1619-1629.

[17] I. Lukes, J. Kotek, P. Vojtisek, P. Hermann, Coord. Chem. Rev. 216-217 (2001) 287312. 
[18] J. Notni, P. Hermann, J. Havlickova, J. Kotek, V. Kubicek, J. Plutnar, N. Loktionova, P.J. Riss, F. Rösch, I. Lukes, Chem. Eur. J. 16 (2010) 7174-85.

[19] J. Šimeček, M. Shulz, J. Notni, J. Plutnar, V. Kubíček, J. Havlíčková, P. Hermann, Inorg. Chem. 51 (2012) 577-590.

[20] M.I.M. Prata, A.C. Santos, C.F.G.C. Geraldes, J.J.P. de Lima, J. Inorg. Biochem. 79 (2000) 359-363.

[21] J.P. André, H.R. Mäcke, J. Inorg. Biochem. 97 (2003) 315-323.

[22] M.I.M. Prata, A.C. Santos, C.F.G.C. Geraldes, J.J.P. de Lima, Nuclear Med. \&Biol. 26 (1999) 707-710.

[23]A. de Sá, M. I. M. Prata, C.F.G.C. Geraldes, J.P. André, J. Inorg. Biochem. 104 (2010) 1051-1062.

[24] A. de Sá, Á. A. Matias, M. I. M. Prata, C.F.G.C. Geraldes, P. M. T. Ferreira, J. P. André, Bioorg. Med. Chem. Lett.20 (2010) 7345-7348.

[25] M.F. Ferreira, G. Pereira, J.P. André, M.I.M. Prata, P.M.T. Ferreira, J.A. Martins, C.F.G.C. Geraldes, Dalton Trans. 43 (2014) 8037-8047.

[26] C. F. G. C. Geraldes, A.D. Sherry, W. P. Cacheris, Inorg. Chem., 28 (1989) 3336 3341.

[27] C.F.G.C. Geraldes, M.C. Alpoim, M.P.M. Marques, A.D. Sherry, M. Singh, Inorg. Chem., 24 (1985) 3876-3881.

[28] A. Bevilacqua, R.I. Gelb, W.B. Hebard, L.J. Zompa, Inorg. Chem., 26 (1987) 26992706.

[29] E.T. Clarke, A.E. Martell, Inorg. Chim. Acta, 181 (1991) 273-328.

[30] E. Farkas, T. Fodor, F.K. Kámán, G. Tircsó, I. Tóth, React. Kinet. Mech. Cat., 116 (2015) 19-33. 
[31] F. Marques, L. Gano, M.P. Campello, S. Lacerda, I. Santos, L.M.P. Lima, J. Costa, P. Antunes, R. Delgado, J. Inorg. Biochem., 100 (2006) 270-280.

[32] V. Kubíček, J. Havlíčková, J. Kotek, G. Tircsó, P. Hermann, É. Tóth, I. Lukeš, Inorg. Chem., 49 (2010) 10960-10969.

[33] J. Mason (Ed.), Multinuclear NMR, Plenum Press, New York, 1987.

[34] R.C. Mathews, D. Parker, G. Fergusson, B. Kaitner, A. Harrison, L. Royle, Polyhedron, 10 (1991) 1951-1953.

[35] D. Shetty, S.Y. Choi, J.M. Jeong, L. Hoigebazar, Y.-S. Lee, D.S. Lee, J.-K. Chung, M.C. Lee, Y.K. Chung, Eur. J. Inorg. Chem., (2010) 4532-4538.

[36] C.F.G.C. Geraldes, A.D. Sherry, G.E. Kiefer, J. Magn. Reson., 97 (1992) 290-304.

[37] M.P.M. Marques, C.F.G.C. Geraldes, A.D. Sherry, A.E. Merbach, H. Powell, D. Pubanz, S. Aime, M. Botta, J. Alloys and Compounds, 225, (1995) 303-307.

[38] F.K. Kálmán, Z. Baranyai, I. Tóth, I. Bányai, R. Király, E. Brücher, S. Aime, X. Sun, A.D. Sherry, Z. Kovács, Inorg. Chem. 47 (2008) 3851 - 3862.

[39] M.P.C. Campello, S. Lacerda, I.C. Santos, G.A. Pereira, C.F.G.C. Geraldes, J. Kotek, P. Hermann, J. Vaněk, P. Lubal, V. Kubíček, É. Tóth, I. Santos, Chem. Eur. J., 28 (2010) 8446-8465.

[40] V.A. Levin, J. Med. Chem., 23 (1980) 682-684.

[41] J.F. Vallabhajosa, J.K. Harwig, N. Siemsen, W. Wolf, J. Nucl. Med. 21 (1980) 650656.

[42] W.R. Harris, V.L. Pecoraro, Biochemistry, 22 (1983) 292-299.

[43] K.-P. Eisenwiener, M. I. M. Prata, I. Buschmann, H.-W. Zhang, A. C. Santos, S. Wenger,| J.- C. Reubi, H. R. Maecke, Bioconjugate Chem. 13 (2002) 530-541. 
[44] M.I. Kabachnik, T.Y. Medved, Y.M. Polikarpov, B.K. Shcherbakov, F.I. Bel'skii, E.I. Matrosov, M.P. Pasechnik, Bull. Acad. Sci. USSR, 33 (1984) 769-777.

[45] M. Fellner, P. Riss, N. Loktionova, K. Zhernosekov, O. Thews, C. F. G. C. Geraldes, Z. Kovacs, I. Lukes, F. Rösch, Radiochim. Acta 99 (2011) 43-51.

[46] H.M. Irving, M.G. Miles, L. Pettit, Anal. Chim. Acta, 38 (1967) 475-488.

[47] L. Zékány, I Nagypál (1985) In: D.J. Leggett, (Ed) Computational method for determination of formation constants. Plenum New York, p. 291.

[48] C.F. Baes and R.S. Mesmer, The Hydrolysis of Cations, John Wiley \& Sons, London, 1976.

[49] P.K. Glasoe, F.A. Long, J. Phys. Chem. 64 (1960) 188-190. 


\section{Figures and Captions}

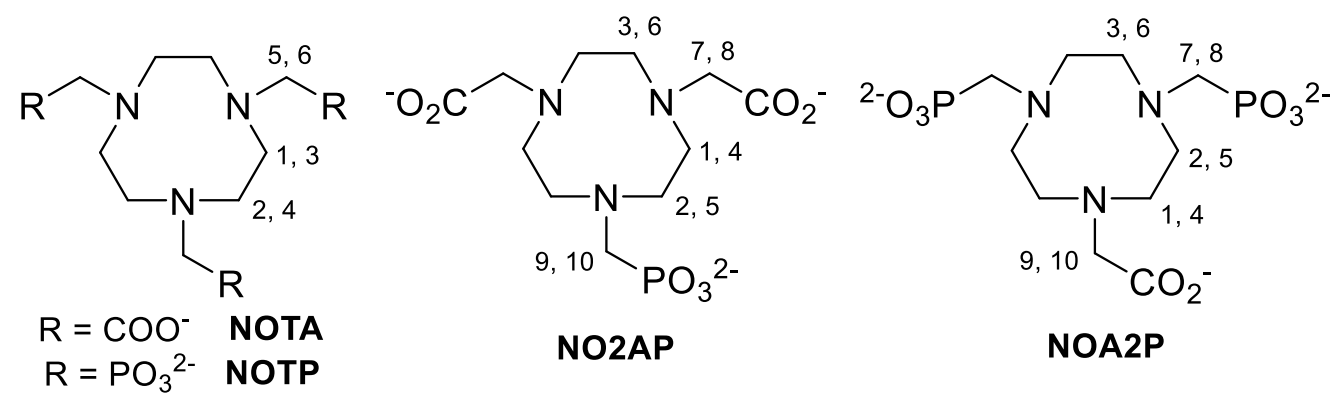

Figure 1. Chemical structures and atoms numbering scheme used for the proton NMR assignments for the triazamacrocyclic ligands investigated in this work. 


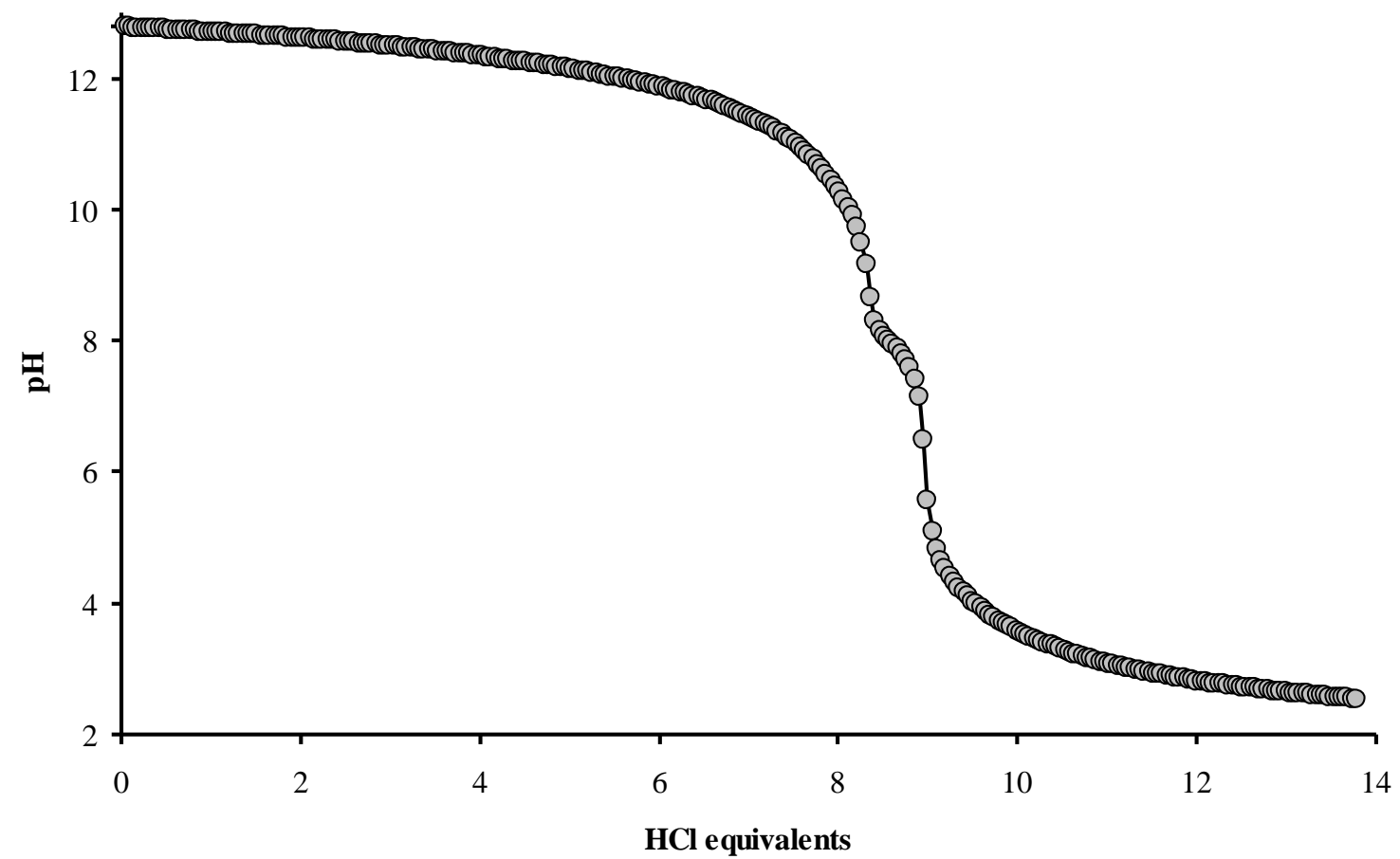

Figure 2. pH-potentiometric titration curve of a solution containing $3.968 \mathrm{mM}$ NOA2P in the presence of $3.938 \mathrm{mM} \mathrm{Ga}^{3+}\left(\mathrm{I}=0.1 \mathrm{M} \mathrm{KCl}, \mathrm{T}=25^{\circ} \mathrm{C}\right)$. The $\mathrm{Ga}^{3+}$ was introduced in the form of gallate in the presence of 5 equivalent excess base. 


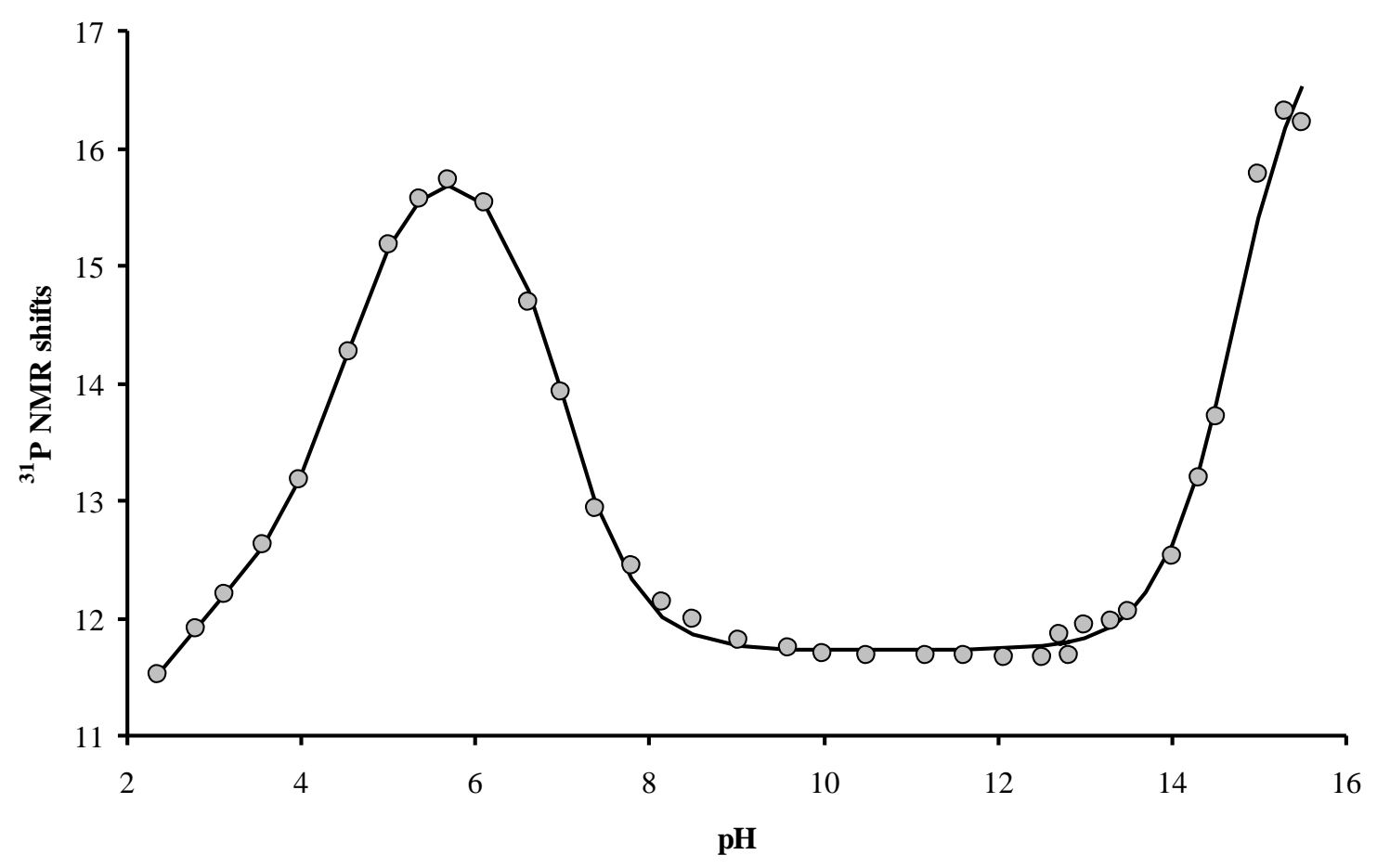

Figure 3. ${ }^{31} \mathrm{P}$ NMR $\mathrm{pH}$ titration of NOA2P ligand (10 mM ligand concentration, Bruker Avance $360 \mathrm{MHz}, \mathrm{T}=25{ }^{\circ} \mathrm{C}$, the ionic background was not controlled). Symbols indicate the measured data, the line is the fitted curve with $\log K_{\mathrm{H} 1}=14.21 \pm 0.09, \log K_{\mathrm{H} 2}=6.48 \pm$ $0.08, \log K_{\mathrm{H} 3}=4.02 \pm 0.09$ and $\log K_{\mathrm{H} 4}=2.1 \pm 0.1$. 


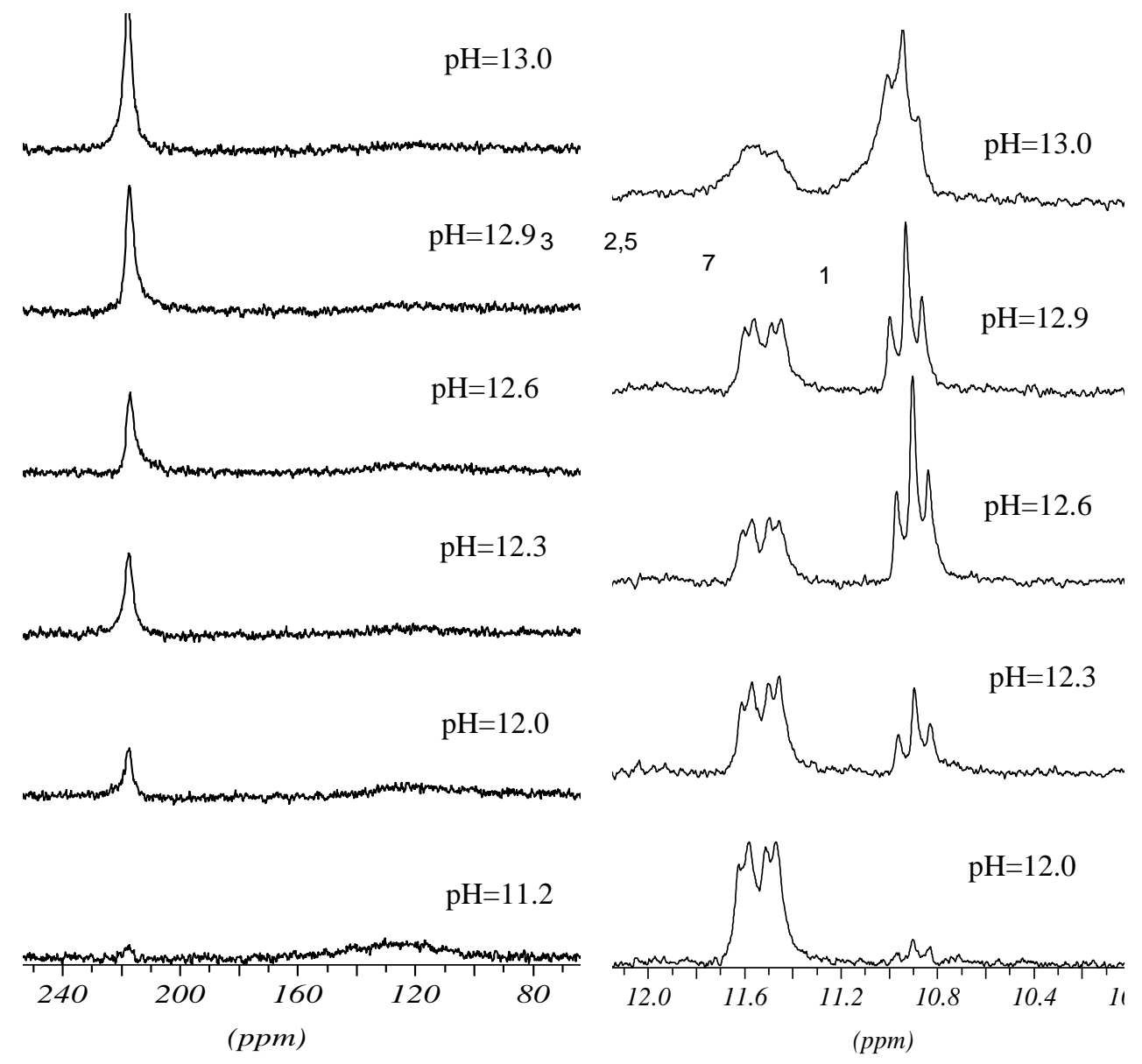

Figure 4. ${ }^{68} \mathrm{Ga}$ NMR spectra (left stack) and ${ }^{31} \mathrm{P}$ NMR spectra (right stack) of $10 \mathrm{mM}$ GaNOA2P solutions at $25{ }^{\circ} \mathrm{C}$ in the $\mathrm{pH}$ range of $11.14-13.0$. 


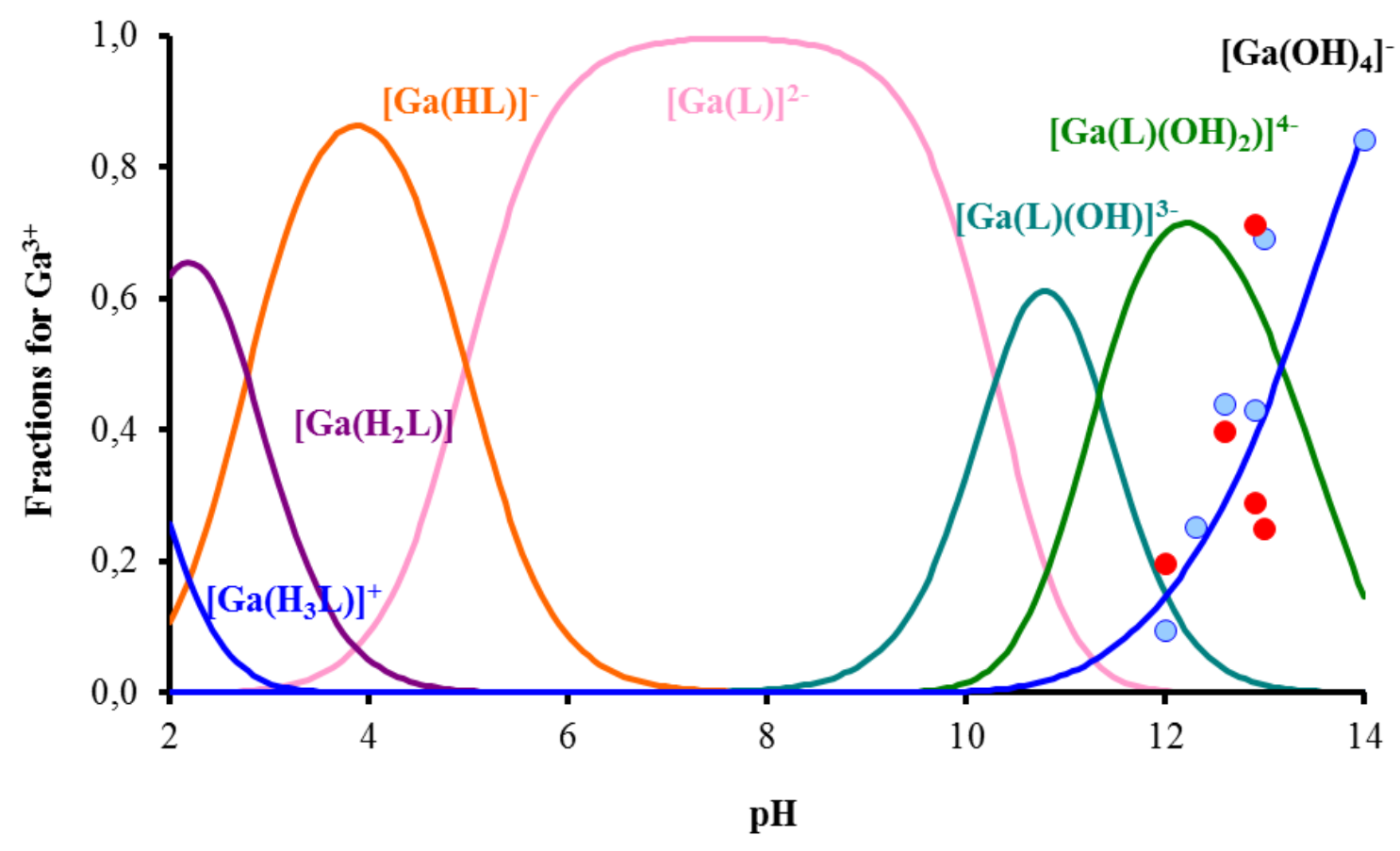

Figure 5. $\mathrm{pH}$ distribution of GaNOA2P species vs $\mathrm{pH}$ calculated from thermodynamic data and concentrations of GaNOA2P complex (blue circles: signals for the complex) and free NO2A2P (red circles: signals for the free ligand) obtained from ${ }^{31} \mathrm{P}$ NMR measurements. 


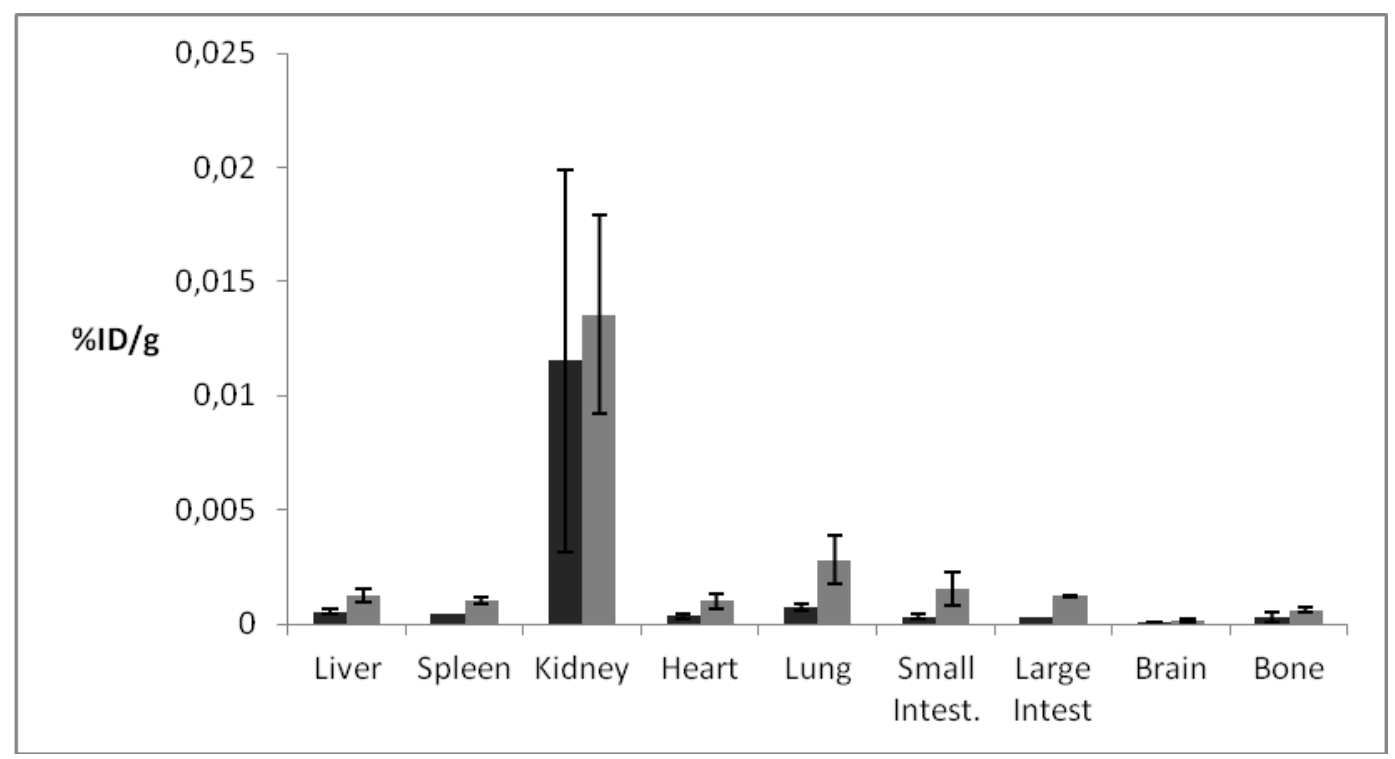

Figure 6. In vivo biodistribution of the ${ }^{67} \mathrm{Ga}^{3+}$ chelates of NOA2P (dark grey) and NO2AP (light grey) in Wistar rat tissues at $2 \mathrm{~h}$ after injection. Values are the mean of 4 animals. 
Table 1. Stepwise protonation constants of various triaza macrocyclic ligands at $25^{\circ} \mathrm{C}$.

\begin{tabular}{|l|c|c|c|c|}
\hline & NOTA & NO2AP & NOA2P $^{\mathrm{a}}$ & NOTP $^{\mathrm{a}}$ \\
\hline $\log K_{\mathrm{H} 1}$ & $11.3^{\mathrm{h}} ; 11.73^{\mathrm{i}} ;$ & $-^{\mathrm{l}}$ & $14.21 \pm 0.09^{\mathrm{d}, \mathrm{l}}$ & $15.2 \pm 0.2^{\mathrm{d}}, 14.50 \pm 0.01^{\mathrm{e}}$ \\
& $11.96^{\mathrm{j}} ; 11.79^{\mathrm{k}}$ & & $12.98 \pm 0.10^{\mathrm{c}}$ & $\left(11.7^{\mathrm{f}} ; 12.1^{\mathrm{g}}\right)$ \\
$\log K_{\mathrm{H} 2}$ & $5.59^{\mathrm{h}} ; 5.74^{\mathrm{i}} ;$ & $7.16 \pm 0.05^{\mathrm{c}}$ & $8.19 \pm 0.35^{\mathrm{c}}$ & $9.11 \pm 0.03^{\mathrm{e}}$ \\
& $5.65^{\mathrm{j}} ; 5.84^{\mathrm{k}}$ & & & $\left(9.1^{\mathrm{f}} ; 9.4^{\mathrm{g}}\right)$ \\
$\log K_{\mathrm{H} 3}$ & $2.88^{\mathrm{h}} ; 3.16^{\mathrm{i}} ;$ & $4.90 \pm 0.08^{\mathrm{c}}$ & $6.48 \pm 0.09^{\mathrm{d}}$ & $8.02 \pm 0.03^{\mathrm{e}}$ \\
& $3.17^{\mathrm{j}} ; 3.36^{\mathrm{k}}$ & & $6.29 \pm 0.15^{\mathrm{c}}$ & $\left(7.5^{\mathrm{f}} ; 7.5^{\mathrm{g}}\right)$ \\
$\log K_{\mathrm{H} 4}$ & $1.98^{\mathrm{k}}$ & $2.23 \pm 0.12^{\mathrm{c}}$ & $4.02 \pm 0.09^{\mathrm{d}}$ & $6.77 \pm 0.03^{\mathrm{e}}$ \\
& - & & $4.24 \pm 0.11^{\mathrm{c}}$ & $\left(5.8^{\mathrm{f}} ; 5.9^{\mathrm{g}}\right)$ \\
$\log K_{\mathrm{H} 5}$ & - & - & $2.1 \pm 0.1^{\mathrm{d}}$ & $5.56 \pm 0.03^{\mathrm{e}}$ \\
& - & - & $2.38 \pm 0.13^{\mathrm{c}}$ & $\left(3.1^{\mathrm{f}} ; 2.9^{\mathrm{g}}\right)$ \\
$\log K_{\mathrm{H} 6}$ & - & - & - & $3.45 \pm 0.04^{\mathrm{e}}$ \\
& - & - & - & $\left(2.9^{\mathrm{f}}\right)$ \\
$\log K_{\mathrm{H} 7}$ & - & - & & $1.82 \pm 0.03^{\mathrm{e}}$ \\
\hline
\end{tabular}

${ }^{\mathrm{a}}$ This work, literature data on NOTP in parenthesis; ${ }^{\mathrm{b}}$ from potentiometry, $0.1 \mathrm{M} \mathrm{KCl} ;{ }^{\mathrm{c}}$ from ${ }^{1} \mathrm{H} \mathrm{NMR} ;{ }^{\mathrm{d}}$ from ${ }^{31} \mathrm{P}$ NMR; ${ }^{\mathrm{e}}$ from ${ }^{31} \mathrm{P}$ NMR using an $\mathrm{H}_{3} \mathrm{PO}_{4}$ external standard in a capillary; ${ }^{\mathrm{f}}$ from potentiometry, $0.1 \mathrm{M} \mathrm{NaCl}$ [26]; ${ }^{\mathrm{g}}$ from potentiometry, $0.1 \mathrm{M} \mathrm{NMe}_{4} \mathrm{Cl}$ [26]); ${ }^{\mathrm{h}}$ from potentiometry and ${ }^{1} \mathrm{H} \mathrm{NMR}, 0.1 \mathrm{M} \mathrm{NaClO}_{4}$ [27]; ${ }^{\mathrm{i}}$ from potentiometry, $0.1 \mathrm{M} \mathrm{NaNO}_{3}$ [28]; ${ }^{\mathrm{j}}$ from potentiometry, $0.1 \mathrm{M} \mathrm{KCl}$ [29]; ${ }^{\mathrm{k}}$ from potentiometry, $0.15 \mathrm{M}$ $\mathrm{NaCl}[30] ;{ }^{1}$ could not be determined with an acceptable accuracy or precision. 
Table 2. Stability constant $\left(\log K_{\mathrm{GaL}}\right.$ ) of the $\mathrm{Ga}^{3+}$ complex of NOA2P and its protonation constants $\left(\log K^{\mathrm{Hi}} \mathrm{GaL}\right.$ and $\left.\log K^{\mathrm{OH}} \mathrm{GaL}\right)$ at $25^{\circ} \mathrm{C}$ in $\mathrm{KCl} 0.1 \mathrm{M}$ in comparison with other $\mathrm{Ga}^{3+}$ complexes (GaNOTA and GaDOTA).

\begin{tabular}{|l|c|c|c|}
\hline \multicolumn{1}{|c|}{ Species } & NOTA $^{\mathrm{a}, \mathrm{b}}$ & NOA2P & DOTA \\
\hline $\mathrm{GaL}$ & $28.96^{\mathrm{a}}, 30.98^{\mathrm{b}}$ & $34.44 \pm 0.04$ & $24.95^{\mathrm{a}}, 26.05^{\mathrm{c}}$ \\
\hline $\mathrm{GaHL}$ & $1.75^{\mathrm{a}},-^{\mathrm{b}}$ & $4.98 \pm 0.10$ & $3.26^{\mathrm{a}}, 3.64^{\mathrm{c}}$ \\
\hline $\mathrm{GaH}_{2} \mathrm{~L}$ & - & $2.76 \pm 0.09$ & $-^{\mathrm{a}}, 2.43^{\mathrm{c}}$ \\
\hline $\mathrm{GaH}_{3} \mathrm{~L}$ & - & $1.61 \pm 0.09$ & $-^{\mathrm{a}}, 1.84^{\mathrm{c}}$ \\
\hline $\mathrm{Ga}(\mathrm{OH}) \mathrm{L}$ & $10.30^{\mathrm{a}}, 9.70^{\mathrm{b}}$ & $10.29 \pm 0.03$ & - \\
\hline $\mathrm{Ga}(\mathrm{OH})_{2} \mathrm{~L}$ & - & $11.33 \pm 0.05$ & - \\
\hline
\end{tabular}

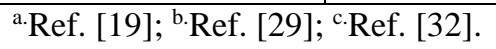


Table 3. ${ }^{71} \mathrm{Ga}$ NMR chemical shifts and linewidths for $\mathrm{Ga}^{3+}$ chelates of triazamacrocyclic ligands. ${ }^{27} \mathrm{Al} \mathrm{NMR}$ data for the corresponding $\mathrm{Al}^{3+}$ chelates are also shown when available $\left({ }^{27} \mathrm{Al}\right.$ shifts are relative to $\left.\left[\mathrm{Al}\left(\mathrm{H}_{2} \mathrm{O}\right)_{6}\right]^{3+}\right)$.

\begin{tabular}{|c|c|c|c|c|}
\hline \multirow[t]{2}{*}{ Ligand } & \multicolumn{2}{|l|}{${ }^{71} \mathrm{Ga}$} & \multicolumn{2}{|l|}{${ }^{27} \mathrm{Al}$} \\
\hline & $\delta(\mathrm{ppm})$ & $\Delta v_{1 / 2}(\mathrm{~Hz})$ & $\delta(\mathrm{ppm})$ & $\Delta v_{1 / 2}(\mathrm{~Hz})$ \\
\hline $\mathrm{H}_{2} \mathrm{O}$ & 0 & 53 & 0 & $3-20$ \\
\hline NOTA & $+171^{\mathrm{a}}$ & $210^{\mathrm{a}}$ & $+49^{\mathrm{b}}$ & $60^{\mathrm{b}}$ \\
\hline NO2AP & $+153^{\mathrm{c}}$ & $914^{c}$ & & \\
\hline NOA2P & $+130^{c}$ & $1528^{c}$ & & \\
\hline NOTP & $+110^{\mathrm{d}}$ & $434^{\mathrm{d}}$ & $+31.9^{b}$ & $205.5^{\mathrm{b}}$ \\
\hline DETA & $+133^{\mathrm{a}}$ & $2000^{\mathrm{a}}$ & $+40.1^{\mathrm{e}}$ & $100.2^{\mathrm{e}}$ \\
\hline UNTA & not observed $^{b}$ & not observed ${ }^{b}$ & & \\
\hline DOTRA & - & $3500^{\mathrm{b}}$ & & \\
\hline NODASA & $+165^{\mathrm{f}}$ & $1000^{f}$ & $+47^{g}$ & $80^{g}$ \\
\hline NOTMA & $+149^{\mathrm{h}}$ & - & & \\
\hline NOTPP & $+132^{\mathrm{i}}$ & $560^{\mathrm{i}}$ & & \\
\hline NOTBzP & $+130^{\mathrm{i}}$ & $1220^{\mathrm{i}}$ & & \\
\hline NOTMP & $+136^{\mathrm{i}}$ & $215^{\mathrm{i}}$ & & \\
\hline NOTAC6 & $+166^{\mathrm{j}}$ & $622^{\mathrm{j}}$ & $+47.5^{j}$ & $54.9^{j}$ \\
\hline NOTAC8 & $+166^{j}$ & $529^{j}$ & $+47.3^{j}$ & $146.6^{j}$ \\
\hline NOTAC16 & not observed ${ }^{\mathrm{j}}$ & not observed $^{\mathrm{j}}$ & $\begin{array}{c}\text { not } \\
\text { observed }^{\mathrm{j}}\end{array}$ & $\begin{array}{c}\text { not } \\
\text { observed }^{\mathrm{j}}\end{array}$ \\
\hline L1 & $+171^{\mathrm{k}}$ & $235^{\mathrm{k}}$ & & \\
\hline L2 & $+175^{\mathrm{k}}$ & $9085^{\mathrm{k}}$ & & \\
\hline L3 & $+141 / 186^{1}$ & $900 / 550^{1}$ & & \\
\hline L4 & $+140^{1}$ & $900^{1}$ & & \\
\hline TRAP-H & $\begin{array}{c}+132 /+134 /+13 \\
8 /+141^{\mathrm{m}}\end{array}$ & $\begin{array}{c}154 / 200 / 186 / 1 \\
62^{\mathrm{m}}\end{array}$ & & \\
\hline
\end{tabular}


NOTA $=$ 1,4,7-triazacyclononane-1,4,7-triacetic acid; DETA = 1,4,7-triazacyclodecane-1,4,7-triacetic acid; $\mathrm{UNTA}=$ 1,4,7-triazacycloundecane-1,4,7-triacetic acid ;DOTRA = 1,4,7-triazacyclododecane-1,4,7-triacetic acid; NODASA = 1,4,7-triazacyclononane-1-succinic acid-4,7-diacetic acid; NOTMA $=(R)-1,4,7$-tris $(29$ methylcarboxymethyl)-triazacyclononane; NOTPP $=$ 1,4,7-triazacyclononane-1,4,7-triyltrimethylenetris (phenylphosphinicacid); NOTBzP = 1,4,7-triazacyclononane-1,4,7-triyltrimethylenetris(benzylphosphinic acid); NOTMP = 1,4,7-triazacyclononane-1,4,7-triyltrimethylenetris(methylphosphinic acid); NOTAC6 = 1,4,7-triazacyclononane-1-hexanoic acid-4,7-diacetic acid; NOTAC8 = 1,4,7-triazacyclononane-1-octanoic acid-4,7-diacetic acid; NOTAC16 = 1,4,7-triazacyclononane-1-hexadecanoic acid-4,7-diacetic acid; L1 = NO2A-N-methylacetamide; L2 = NO2A-N-benzylacetamide; L3 = 1,4,7-triazacyclononane-1aminocarboxyethyl - 4,7-diacetic acid; L4 = 1,4,7-triazacyclononane-1- benzamidocarboxyethyl - 4,7-diacetic acid; TRAP-H = 1,4,7-triazacyclononane-1,4,7-tris(methylenephosphinicacid); ${ }^{\mathrm{a}}[11,12] ;{ }^{\mathrm{b}}[21]$; ${ }^{\mathrm{c}}$ This work; ${ }^{\mathrm{d}}$ [20]; ' Unpublished results; ${ }^{\mathrm{6}}{ }^{8} \mathrm{Ga}$ signal [14]; ${ }^{\mathrm{g}}$ [15]; ${ }^{\mathrm{h}}[34] ;{ }^{\mathrm{i}}$ [16]; ${ }^{\mathrm{j}}$ [23]; ${ }^{\mathrm{k}}$ [35]; ${ }^{\mathrm{l}}$ [25]; ${ }^{\mathrm{m}}$ [19]. 